\title{
Analysis of Tourism Destination Image and Promotion through Social Media Towards Purchasing Decision for Bali Tourism Product by Foreign Tourist
}

\author{
Ngadino Surip Diposumarto \\ Wawan Purwanto
}

Ivan Ramdan

Mercu Buana University; E-mail : dinosurip@gmail.com, wawanpur@gmail.com, ramdani.ivan@gmail.com

Doi:10.5901/mjss.2015.v6n5s5p175

\section{Abstract}

Indonesia as a country which has a tourism potential through its diversity of tourism destinations, need to take take part in enjoying a market share of the world tourism at the global level. Bali province is to be a barometer of the national tourism must be developed by knowing what factor effect tourism visit. This study is aimed to see the influence of some variables that suppose influence in the purchase decision for Bali tourism products by foreign tourists. These variables are the tourism destination image and promotion through social media. Respondents of this study were foreign tourists which visiting Bali in the certain period. This research is using Structural Equation Modeling (SEM). The finding of this research is the tourism destination image is significantly influencing the purchasing decisions of Bali tourism products by foreign tourists. Destination image has a positive effect and significant in terms of influencing purchase decisions. Promotion through social media does not significantly influence the purchasing decisions of Bali tourism products by foreign tourists. Tourism destination image and promotion through social media simultaneously have a significant effect towards purchasing decisions. The result of this study make a conclusion that the country must do something to increase attribute image of tourism destination in order to attract more foreign tourists visit to Bali.

Keywords: Marketing, promotion, purchase decision, social media, tourism

\section{Introducton}

Various international organizations such as the UN, the World Bank and the United Nations World Tourism Organization (UNWTO) have recognized that tourism is an integral part of human life. In the year 2013, the revenue obtained from the world tourism sector is very promising, amounting to USD 1.030 billion, or an average daily revenue of USD 2.8 billion scooped from the industry.

Looking at these developments, Indonesia as a country which has a tourism potential through its diversity of tourism destinations, need to take take part in enjoying a market share of the world tourism at the global level. Bali province is to be a barometer of the national tourism development. Bali Island is not only famous in domestic areas, but also very popular in foreign countries. The tourism sector at a pace not only by the local government, but also as a layer of society. Our stake holder in tourism community for the future must responsibility to raise the foreign tourist visit to Indonesia in order to give better performance, not like we look the table below.

Table 1. The number of foreign tourist arrivals to Bali 2009-2013

\begin{tabular}{lccccc} 
Description & $\mathbf{2 0 0 9}$ & $\mathbf{2 0 1 0}$ & $\mathbf{2 0 1 1}$ & $\mathbf{2 0 1 2}$ & $\mathbf{2 0 1 3}$ \\
\hline Foreign Tourist (x1000) & $2.229,94$ & $2.493,05$ & $2.756,57$ & $2.892,019$ & $3.278,59$ \\
+/- (x1000) & 261,05 & 263,11 & 263,52 & 135,44 & 386,57 \\
\% Growth & $13,2 \%$ & $11,8 \%$ & $10,5 \%$ & $4,9 \%$ & $13,3 \%$ \\
\hline
\end{tabular}

Source: Statistics Dept. of Bali Province, 2014 (processed).

However, tourist arrivals to some destinations and tourism in Bali has a tendency for a decrease in visits (2012-2013), we still hope with variable of this research, the growth of touris visit will recover. 
A factor that can affect the tourist traffic to a tourism destination is the image of tourism destinations, which in this case one of the factors that can be seen is the popularity of tourist destinations, facilities and supporting infrastructure of tourism activities, the quality of the attractions, ease of access for tourists to visit some of the attractions in a tour package as well as the conduciveness or the security of the tourist sites. Increased of traffic jam in some main street in Bali could drive a negative image of Bali Province as a tourism destination. This problem caused from low fund for Bali infrastructure. In fact, infrastructure investment fund in Indonesia still low compare to others ASEAN country.

On the other side, globalization also causes a strong relationship, interplay and sharing in all sides of human life, especially in science, culture and technology, including industry which strongly related to tourism activity. With the existence of the internet, information that needed for a tourism trip available, especially in World Wide Web or Web. Customers nowadays could connect directly with an information source without intermediaries. And now very well known as "new truth" tourism marketers that " online marketing is the main communication in marketing tourism product. No on line so no reach the place to go. Everybody now prepare for their destination with their gadget or computer. Base on this background this research focus to the problem, is the tourism destination image influence the purchasing decisions of Bali tourism products by foreign tourists ? Is the promotion through social media influence the purchasing decisions of Bali tourism products by foreign tourists ? Is Tourism destination image and promotion through social media simultaneously affect on purchase decisions Bali tourism products by foreign tourists?

\section{Literature Review}

\subsection{Tourism destination}

Tourism is a traffic of peoples who leaves their origin for a while and travelling to others place, it happens because they are a customer from the result of the economy and culture to fulfill their needs and culture or their desire (Margenroth in Yoeti, 1996:117). As with any other service industry, the tourism industry also has the properties of intangibility , inseparability, heterogeneity, and perishability. The tourists using the image of a tourist destination as a tool to evaluate the place of their visit ( Andreassen \& Lindestad , 1998: 237 ). The image of the destination has the potential to influence the tourist visit of place ( LeBlanc \& Nguyen , 2002: 243 ). Malhotra (1999 : 89) defines image as " traveler 's perception of the company and its products ". The image is a picture - overall impression created in the traveler's mind Dichter in LeBlanc \& Nguyen (2002 : 176).

\subsection{Promotion Through Social Media}

The success of a marketing program in the field of marketing is largely determined by factors common view of the role of tourism in regional development, because it was before the marketing program implemented there must be a commitment from all relevant elements that tourism is an economic sector that is quick yielding and an agent of development for the related area (Yoeti's, $1996: 76$ ). The companies must allocate promotional budget for the five promotional tools such as advertising , sales promotion, public relations and news, personal selling and direct marketing ( Kotler , 2005: 264 ). Social media is information content, which is made by the people who use technology publishing, it is easily accessible and is intended to facilitate communications, influence and interaction with peers and the general public, (Thoyibie in Ronomenggolo, 2013 : 18).

\subsection{Purchasing Decision}

Purchasing decision is in the stage of purchasing decision process in which consumers actually buy (Kotler and Armstrong, $2005: 226)$. Purchasing decisions is the selection of two or more alternative options. In other words, alternative options should be available to a person when making decisions (Schiffman and Kanuk, 2008:45).

Framework and hypotheses are formed from these theories which is reinforced by previous studies that the author concluded is as follows: 


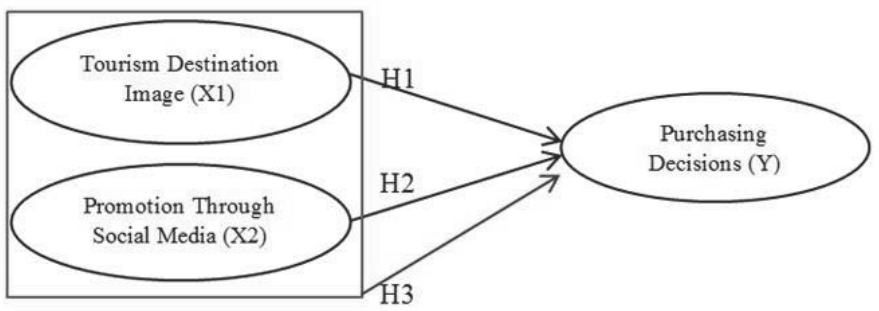

Figure 1: Framework

Hypotheses of the study are $\mathrm{H1}$ :Tourism destination image effect on purchase decisions Bali tourism products by foreign tourists. H2: Promotion through social media effect on purchase decisions Bali tourism products by foreign tourists. H3:Tourism destination image and promotion through social media simultaneously affect on purchase decisions Bali tourism products by foreign tourists.

\section{Research Method}

\subsection{Research Design}

This research approach using a quantitative approach and the type of causality is research that seeks to look at the influence between variables also the influence level. Fieldwork was conducted for 3 ( three ) months, starting from April 2014 to June 2013 in the Bali province. Population in this research is unknown because of the dynamics of tourist arrivals, but the respondents of this study were foreign tourists which visiting Bali in the period April 2014 to June 2014 . The size of sample calculated according to Maholtra formula (2012), that must follow certain amount to fit the requirement research. He say the number is $5 \times$ sub variable $\rightarrow 5 \times 16$ sub variable $=80$ respondents. However, to obtain more representative results as well as the method used is SEM which minimum quantity of the sample is 100 , then the sample size increased to 200 respondents.

\subsection{Operational Definition}

Table 2. Operational Definition of Reseach

\begin{tabular}{|c|c|c|c|c|c|}
\hline Variable of Research & Dimension & & Indicator & & Indicator Number \\
\hline \multirow{5}{*}{$\begin{array}{l}\text { Tourism Destination } \\
\text { Image }\end{array}$} & 1) & Tourism destination quality & 1) & Nature beauty & CDP1 \\
\hline & 2) & Product design & 1) & Availability of tourism package & CDP2 \\
\hline & 3) & Brand & & $\begin{array}{l}\text { Popularity of tourism } \\
\text { destination }\end{array}$ & CDP3 \\
\hline & 4) & Emotional considerations & 1) & Country security & CDP4 \\
\hline & 5) & Social environment & 1) & $\begin{array}{l}\text { Friendliness as Indonesia culture } \\
\text { Good management }\end{array}$ & $\begin{array}{l}\text { CDP5 } \\
\text { CDP6 }\end{array}$ \\
\hline $\begin{array}{l}\text { Promotion Through } \\
\text { Social Media }\end{array}$ & 1) & Internet Medias & $\begin{array}{l}\text { 1) } \\
\text { 2) } \\
\text { 3) } \\
\text { 4) } \\
\text { 5) }\end{array}$ & $\begin{array}{l}\text { Website } \\
\text { Facebook } \\
\text { Twitter } \\
\text { Instagram } \\
\text { Youtube } \\
\end{array}$ & $\begin{array}{l}\text { SMM1 } \\
\text { SMM2 } \\
\text { SMM3 } \\
\text { SMM4 } \\
\text { SMM5 }\end{array}$ \\
\hline \multirow{4}{*}{ Purchasing Decision } & 1) & Price value & 1) & Reasonable price & ITB1 \\
\hline & 2) & Product value & 1) & Interesting destination area & $\begin{array}{l}\text { ITB2 } \\
\text { ITB3 }\end{array}$ \\
\hline & 3) & Promotion value & 1) & Wellknown area & ITB4 \\
\hline & 4) & Communication value & 2) & Image & ITB5 \\
\hline
\end{tabular}




\section{Research Result and Discussion}

\subsection{Validiy Test}

Based on the results of the validation test of the questionnaire for the 16 questions on the tourism destination image variables, promotion through social media and purchasing decisions, each of the correlation of each indicator is positive and the value is above of $r$-table 0.3 , then the whole point is valid instruments.

\subsection{Reliability Test}

Based on the results of the reliability test of the 16 questions for variable image of tourism destinations, promotion through social media and purchasing decisions where these results indicate that the value Crobach's Alpha above 0.6 so of these indicators can be concluded that the measurement scale whole grains instrument image of tourism destinations, promotion through social media and purchasing decisions declared reliable.

\subsection{Model Test for Tourism Destination Image Variable}

Based on test results using SPSS, variable of the tourism destinations image has 6 indicators are valid and reliable. In testing the model of tourism destination image variable using LISREL program, also showed it 6 indicator has a standardized loading factor value of $>0.5$. The model of tourism destination image variables have Chi-square numbers $=$ 50.49 , $\mathrm{df}=9$, P-value $=0.00000$, and the RMSEA was 0.152 . This is mean that the model variables of this study ( the tourism destinations image) is fit with the data or in the other hand, the model proposed is able to estimate the population covariance matrix which is not different from the sample data covariance matrix.

\subsection{Model Test for Promotion Through Social Media Variable}

Based on test results using SPSS, variable of promotion through social media has 5 indicators are valid and reliable. In testing the model of promotion through social media variables using LISREL program, also showed it 5 indicator has a standardized loading factor value of $>0.5$. The model of promotion through social media variables have Chi-square numbers $=72.67, \mathrm{df}=5, \mathrm{P}$-value $=0.00000$, and the RMSEA was 0.261 . This is mean that the model variables of this study ( promotion through social media) is fit with the data or in the other hand, the model proposed is able to estimate the population covariance matrix which is not different from the sample data covariance matrix.

\subsection{Model Test for Purchasing Decision Variable}

Based on test results using SPSS, variable of purchasing decision has 5 indicators are valid and reliable. In testing the model of purchasing decision variables using LISREL program, also showed it 5 indicator has a standardized loading factor value of $>0.5$. The model of purchasing decision variable have Chi-square numbers $=44.46, \mathrm{df}=5, \mathrm{P}$-value $=$ 0.00000 , and the RMSEA was 0.199 . This is mean that the model variables of this study (purchasing decisions) is fit with the data or in the other hand, the model proposed is able to estimate the population covariance matrix which is not different from the sample data covariance matrix.

\subsection{Model Test for Overall Variables}

The overall model test is performed to determine whether the variables that the model is made in accordance with the existing data. The results of the overall model test variables can be seen in figure below. 


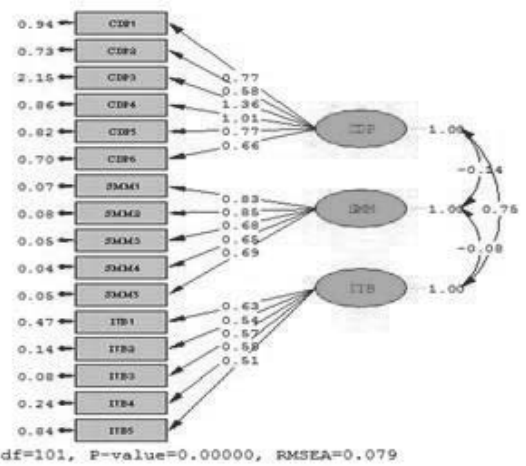

Figure 2. Model Test for Overall Variables

Table 3. Result of Overall Variable Test

\begin{tabular}{clccl}
\hline No. & Goodness of Fit Statistics & Ideal Value & Model Value & Remark \\
\hline 1. & Root Mean Square Error of Approximation (RMSEA) & $\leq 0,08$ & 0,079 & Good Fit \\
2. & Normed Fit Index (NFI) & $\geq 0,90$ & 0,93 & Good Fit \\
3. & Non-Normed Fit Index (NFII) & $\geq 0,90$ & 0,95 & Good Fit \\
4. & Comparative Fit Index (CFI) & $\geq 0,90$ & 0,96 & Good Fit \\
5. & Incremental Fit Index (IFI) & $\geq 0,90$ & 0,96 & Good Fit \\
6. & Relative Fit Index (RFI) & $\geq 0,90$ & 0,92 & Good Fit \\
7. & Goodness of Fit Index (GFI) & $\geq 0,90$ & 0,87 & Marginal Fit \\
8. & Adjusted Goodness of Fit Index & $\geq 0,90$ & 0,83 & Marginal Fit \\
\hline
\end{tabular}

Source: Data processed by writer - Lisrel's output (2014)

Information obtained from the CFA, although results of conformity test model gives the probability of the chi-square value is at 0.00 , but the RMSEA $(0.0790 .08)$ and CFI $(0.96>0.90)$ and the coefficient weighting factors is above 0.40 . This means that the proposed model is able to estimate the population covariance matrix which not different from the sample data covariance matrix. This is indicating that the estimation results obtained from the sample data can be used as the basis for making generalizations about the phenomenon being researched.

\subsection{Structural Model Test (Hypotheses Test)}

A structural model test was conducted to test the relationship between variables which is described in the hypothesis. The overall structural model can be seen in figure 3 and 4 .
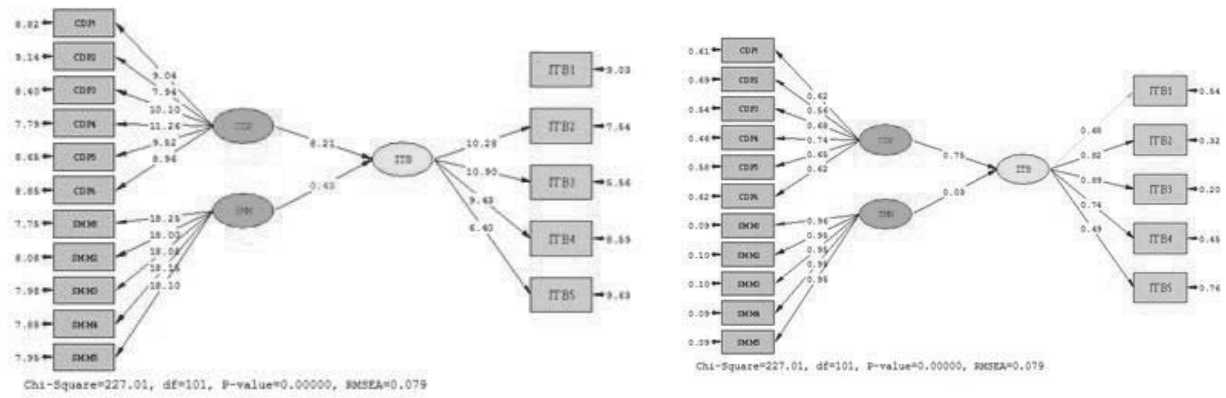

Figure 3: Overall Variable Model Test (Standardized) Figure 4: Overall Variable Model Test ( $t$-values) 
After syntax being save and run, conformance test results obtained (Table V.4) that the value of degrees of freedom is 101 , although the probability of the chi-square value is at 0.00 but the RMSEA value $(0.079<0.08)$. It can be concluded that the proposed model fits with the data. CFI values $(0.96>0.90)$ indicating overall model shows a fit. Summary results of the overall measurement variables can be seen in table 4.4 below:

Table 4. Goodness of Fit Overall Structural Variable Model

\begin{tabular}{clccl}
\hline No. & Goodness of Fit Statistics & Ideeal Value & Ideal Value & Remark \\
\hline 1. & Root Mean Square Error of Approximation (RMSEA) & $\leq 0,08$ & 0,079 & Good Fit \\
2. & Normed Fit Index (NFI) & $\geq 0,90$ & 0,94 & Good Fit \\
3. & Non-Normed Fit Index (NFII) & $\geq 0,90$ & 0,96 & Good Fit \\
4. & Comparative Fit Index (CFI) & $\geq 0,90$ & 0,96 & Good Fit \\
5. & Incremental Fit Index (IFI) & $\geq 0,90$ & 0,96 & Good Fit \\
6. & Relative Fit Index (RFI) & $\geq 0,90$ & 0,93 & Good Fit \\
7. & Goodness of Fit Index (GFI) & $\geq 0,90$ & 0,88 & Marginal Fit \\
8. & Adjusted Goodness of Fit Index & $\geq 0,90$ & 0,83 & Marginal Fit \\
\hline
\end{tabular}

Source: Data processed by writer - Lisrel's output (2014)

The results of structural equation 4.5 can be summarized in the following table:

Table 5. Coefficient Evaluation Model and Relation to Hypothesis

\begin{tabular}{ccccl}
\hline Hypotheses & Path & Estimation & Statistics Test & Conclusion \\
\hline 1 & $\mathrm{CDP} \rightarrow$ ITB & 0.75 & $8.21>1.96$ & Related and Significant (H1 Accepted) \\
\hline 2 & $\mathrm{SMM} \rightarrow$ ITB & 0.02 & $0.43<1.96$ & Not Significantly Related (H2 Rejected) \\
\hline
\end{tabular}

Source: Data processed by writer - Lisrel's output (2014)

From the Image 4.5, informed that test results towards estimate coefficient of the overall weight factor significant at the $5 \%$ level of error with standardized coefficient weighting factor values are is greater than the required minimum value of 0.40. This means that each indicator has adequate validity and reliability in measuring the latent variables being researched.

From the t-test statistics of parameter model on the path coefficient was found that the tourism destination image towards purchase decisions significantly by 8.21 (> 1.96), so the $\mathbf{H 1}$ hypothesis can be accepted. On the other hand, it can be seen that the estimated path coefficients between promotion through social media towards purchasing decisions is not significantly impact at the $5 \%$ error rate which is equal to $0.43(<1.96)$, thus hypothesis $\mathrm{H} 2$ is rejected.

Information obtained from the structural equation as outlined below implies that there is a positive and significant relationship (can be generalized to the population where the sample was taken) between CDP (the tourism destination image) with ITB (purchase decisions). This means that if the CDP enhanced it will increase the ITB. Effect of CDP to the ITB is known through a regression coefficient of 0.75 or in other conclusion can be interpreted by $\mathrm{R}^{2}$ that $56 \%$ variants occur in the ITV variable influenced by variables CDP (tourism destination image) and the remaining $44 \%$ are other variables that influence unexplained by the model. Thus, more intensive and focused on activities to build and strengthen the CDP may further improve the ITB. The results of the significance test of each structural model parameter estimation are illustrated by the estimated structural equation as follows:
ITB $=0.75$
$(0.060)$
0.44
$\mathrm{R}^{2}=0.56$
8.21
$(0.096)$

Furthermore, there is a positive correlation between the CDP (the tourism destination image) and SMM (promotion through social media) simultaneously towards ITB (purchase decisions). This means that the level of ITB is influenced by CDP (the tourism destination image) and SMM (promotion through social media) which conducted simultaneously. The two independent variable effect simultaneously to dependent variabel base on the value of $F$ statistic 15.6 which indicated higher than significant requirement. Is the coefficient correlation can be generalized or not, it significance must be tested with the formula: 


$$
F_{h}=\frac{R^{2} / k}{\left(1-R^{2}\right) /(n-k-1)}
$$

$\mathrm{R}^{2}=0.56, \mathrm{k}=2, \mathrm{n}=200 \mathrm{Fh}=15.6$

Calculated $\mathrm{F}$ is obtained based on the above calculation is then compared with the $\mathrm{F}$ table. $\mathrm{F}$ table value with error degrees 0.05 , umerator $\mathrm{dk}=2$ and denominator $\mathrm{dk}$ of 200 , the obtained $\mathrm{F}$ table $=3.04$. It turned out that the calculated $\mathrm{F}$ is greater than $\mathrm{F}$ table (15.6>3.04). Thus it can be stated that the correlation coefficient is significant or can be applied to the population in which the sample is taken so that the conclusions drawn in $\mathrm{H} 3$ is accepted.

Other analysis, the correlation dimension is used to determine the relationship between the most powerful dimension of the variables that have a relationship and effect in accordance with the test model has been done. In correlation dimension, the researchers conducted a correlation analysis between variables and dimensions, the correlation values are taken from the highest $r$ values and are summarized in the following table:

Table 5. Table Analysis between Dimensions

\begin{tabular}{|c|c|c|c|c|c|}
\hline & \multirow[b]{2}{*}{ Dimensions } & \multicolumn{4}{|c|}{ Purchasing Decision $(\mathrm{Y})$} \\
\hline & & $\begin{array}{c}\text { Price Value } \\
\text { (Y1.1) }\end{array}$ & $\begin{array}{l}\text { Product Value } \\
\text { (Y1.2) }\end{array}$ & $\begin{array}{l}\text { Promotion Value } \\
\text { (Y1.3) }\end{array}$ & $\begin{array}{c}\text { Communication Value } \\
\text { (Y1.4) }\end{array}$ \\
\hline \multirow{5}{*}{$\begin{array}{c}\text { Tourism } \\
\text { Destination Image } \\
\text { (X1) }\end{array}$} & Tourism destination quality (X1.1) & 0.176 & 0.413 & 0.287 & 0.139 \\
\hline & Product Design (X1.2) & 0.328 & 0.434 & 0.455 & 0.215 \\
\hline & Brand (X1.3) & 0.282 & 0.413 & 0.396 & 0.224 \\
\hline & Emotional Consideration (X1.4) & 0.396 & 0.387 & 0.358 & 0.171 \\
\hline & Social Environment (X1.5) & 0.375 & 0.399 & 0.381 & 0.216 \\
\hline
\end{tabular}

Source: Data processed by writer - Lisrel's output (2014)

From table above, it can be concluded that there is a relationship and linkages between tourism destination image which is the independent variable in the purchase decision (dependent variable).

From tourism destination image variables - X1, based on the table above, influence of the product design to the promotional value has a correlation value of 0.455 which is the value of the correlation $(r)$ is the highest in the tourism destination image variables influence the purchasing decision, if interpreted, correlation is medium because the values are in the range of $0.400-0.599$. It means that with the availability of a good Bali tourism package will be able to increase the value of Bali tourism products and will affect purchasing decisions Bali tourism product by foreign tourists.

\section{Conclusions and Recommendations}

\subsection{Conclusion}

Conclusion of this research is the tourism destination image is significantly influencing the purchasing decisions of Bali tourism products by foreign tourists. Destination image has a positive effect and significant in terms of influencing purchase decisions (t-value greater than 1.96 which is 8.21). It can be concluded that the better tourism destination image will be influenced positively foreign tourists to buy Bali tourism products. Promotion through social media does not significantly influence the purchasing decisions of Bali tourism products by foreign tourists because of the t-value is less than 1.96 is 0.43 . This can be caused by most tourists decide to travel to Bali as a destination image that has been heard before or based on an observation which made through various sources that are still in common use that is through the experience of fellow lovers of travel, books or of families living in Bali. Tourism destination image and promotion through social media simultaneously have a significant effect towards purchasing decisions (calculated $F$ value 15.6, greater than $\mathrm{F}$ table 3:04). It is very possible considering collaboration of these two variables will be a force in boosting the popularity of tourism destinations. Good image of the destinations needs to be disseminated to the world eyes and the media which possible for this is social media, which is not limited to space and time. By this, it will increase the possibility for foreign tourists to come and visit to Bali in particular and Indonesia in general. 


\subsection{Recommendations}

Suggestions for operational improvements to the government is to further develop diverse tourism packages to attract more foreign tourists to come to Bali in particular, this recommendation is based on the analysis of the dimensions conducted by the researcher in Chapter $\mathrm{V}$, which is based on the results, the dimension which have the highest correlation is a product design towards the promotional value. Products design that can be developed such as by developing a tourism package that covers all types of tourism in Bali, for example: Leisure Travel (beach and mountain), cultural tours (traditional dance), religion (worship temples, ceremonial), shopping (Sukowati market) and culinary (Jimbaran) in one package, so travelers will know that Bali is not only Kuta beach, but more than that, Bali has many tourist destinations that have not been widely recognized by the international community. With the existence of this tour package, then the foreign tourists when returning to their respective countries, they would have the potential to spread the presence of tour package in Bali which allows tourists to visit various tourist spots in the one-time tourist trips (promotional value). Future studies can more focus on security and tourism supporting infrastructure variables which indicated an influence on purchase decisions of Bali tourism products by foreign tourists.

\section{References}

Andreasen, Wallin dan Lindestad, Bodil. 1998. Customer Loyality and Complex Services. Norway: MCB UP

Arwiedya, M. Rizki. 2012. Analisis pengaruh harga, jenis media promosi, resiko kinerja dan keragaman produk terhadap keputusan pembelian via internet pada toko online. Tesis (tidak diterbitkan). Semarang : Universitas Diponegoro

Berger, Jonah. 2007. The influence of product variety on brand perceiption and choices. California : Stanford University.

Berthon, et al. 2012. Marketing Meets Web 2.0, Social Media and Creative Consumers : Implications for International Marketing Strategy. Indiana : Business Horizons.

Chernev. 2003. Product Assortment and Individual Decision Process. Illinois : Nortwestern University

Darmawan, Andriyanto. 2010. Analisis pengaruh internet marketing terhadap pembentukan word of mouth dan Brand awareness untuk memunculkan intention to buy. Tesis (tidak diterbitkan). Bandung : Institut Teknologi Bandung.

Gautama, E. Aulia. 2011. Pengaruh keragaman produk, pendapatan dan pelayanan terhadap keputusan pembelian elektronik merek Polytron. Tesis (tidak diterbitkan). Semarang : Universitas Semarang.

Hann, Jungpill.2009. Knowledge Management Systems and Organizational Knowledge Processing Challenges. Lafayete : Purdue University.

Jongpil, Park. 2012. The salince of social media marketing in the tourism industry. Seoul : Yonsei University.

Kotler, Philip dan Armstrong. 2005. Manajemen Pemasaran, Edisi Millenium. Jakarta : PT Prenhallinda.

Kusumandani, W. Dwi. 2012. Pengaruh Kualitas Pelayanan pada Reputasi Lembaga, Studi pada BNPTKI. Skripsi (tidak diterbitkan). Jakarta : Universitas Indonesia.

Kusumastuti. 2009. Sikap terhadap iklan pada pengguna facebook. Jakarta : Universitas Bina Nusantara.

Malhotra, N.K. 2012 , Basic Marketing Research. Integration of social media. Boston: Pearson

Merlina. 2010. Analisa pengaruh reputasi perusahaan dan pengalaman masa lampau terhadap kepercayaan pelanggan yang berdampak kepada perilaku word of mouth konsumen. Tesis (tidak diterbitkan). Jakarta : Universitas Bina Nusantara.

Miller, Rohan. 2009. Social Media and its Implications for Viral Marketing. Sydney : The University of Sydney.

Nguyen dan LeBlanc. 2002. Journal of Management and Marketing Research. Massachussets : Lexington.

Nurhasanah. 2010. Analisis Pengaruh Keragaman Produk, Kualitas Pelayanan dan Kepuasan Pelanggan Terhadap Loyalitas Pelanggan pada PT. Hero Supermarket. Skripsi (tidak diterbitkan). Jakarta : UIN Syarif Hidayatullah

Nuryati, Lena. 2008. Pengaruh variasi dan kemasan produk terhadap keputusan pembelian teh kotak ultrajaya. Tesis (tidak diterbitkan). Bandung : Universitas Pendidikan Indonesia.

Ronomenggolo, Sigit. 2013. Analisis Pengaruh Promosi Berbasis Sosial Media Terhadap Keputusan Pembelian Konsumen pada Produk ROVCA. Tesis (tidak diterbitkan). Makassar : Universitas Hassanudin.

Schiffman, Leon, And Kanuk, L. Lazar. 2008. Consumer Behaviour 7th Edition (Perilaku Konsumen). Jakarta : PT. Indeks.

Sugiyono. 2012. Metode Penelitian Bisnis. Bandung : Alfabeta

Yoeti, Oka A. 1996. Pengantar Ilmu Pariwisata. Bandung : Angkasa. 